\title{
Influence of diagenetic processes and terrestrial/anthropogenic sources in the REE contents of the Cascais submarine canyon (Iberian western coast)
}

\author{
Mário Mil-Homens ${ }^{\mathrm{a}, \mathrm{b}, *}$, Pedro Brito ${ }^{\mathrm{a}, \mathrm{b}}$, Miguel Caetano ${ }^{\mathrm{a}, \mathrm{b}}$, Ana Maria Costa ${ }^{\mathrm{c}, \mathrm{d}}$, Susana Lebreiro ${ }^{\mathrm{e}}$, \\ Maria Trancoso ${ }^{\mathrm{f}}$, Henko de Stigter ${ }^{\mathrm{g}}$ \\ a IPMA - Portuguese Institute of Sea and Atmosphere, Division of Oceanography and Marine Environment, Rua Alfredo Magalhães Ramalho, 6, 1495-165 Algés, Portugal \\ ${ }^{\mathrm{b}}$ CIIMAR - Interdisciplinary Centre of Marine and Environmental Research, Terminal de Cruzeiros de Leixões. Av. General Norton de Matos, s/n 4450-208 Matosinhos, Portugal \\ c LARC/DGPC, Laboratório de Arqueociências and CIBIO/InBIO, Calçada do Mirante à Ajuda, 10A, 1300-418 Lisboa, Portugal \\ d IDL - Instituto Dom Luíz, University of Lisbon - FCUL, Campo Grande Edificio C1, 1749-016 Lisboa, Portugal \\ e IGME - Instituto Geológico y Minero de España, Área de Geología Marina, Calle Ríos Rosas, 23, 28003 Madrid, Spain \\ ${ }^{\mathrm{f}}$ LNEG - Laboratório Nacional de Energia e Geologia, Laboratório de Biocombustíveis e Biomassa, Estrada do Paço do Lumiar, 22, Ed. E, 1649-038 Lisboa, Portugal \\ ${ }^{g}$ NIOZ, Royal Netherlands Institute for Sea Research, Department of Ocean Systems, 1790 AB Den Burg, the Netherlands
}

\section{H I G H L I G H T S}

- REE contents were measured in two sediment cores of the Cascais submarine canyon (CSC).

- PAAS-normalized REE patterns show input of Tagus contaminated sediment at the CSC shallower site.

- Influence of diagenetic processes is reflected in the LREE signal at the deeper site.

- The signature of anthropogenic $\mathrm{Pb}$ and $\mathrm{Hg}$ contamination is clearer in CSC than that of REE.

- REE cannot be considered as contaminants of emerging concern in the CSC sediments.

\section{G R A P H I C A L A B S T R A C T}
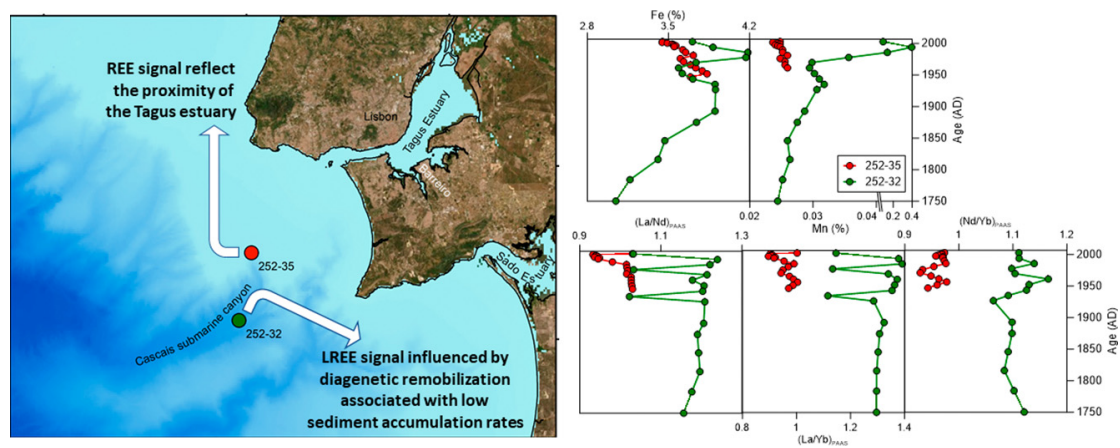

\section{A R T I C L E I N F O}

\section{Article history:}

Received 15 September 2020

Received in revised form 17 January 2021

Accepted 25 January 2021

Available online 3 February 2021

Editor: Julian Blasco

\section{Keywords:}

Portuguese margin

Cascais submarine canyon

Marine sediments

Temporal variability

\begin{abstract}
A B S T R A C T
Temporal variations of rare earth elements (REE) and their fractionation patterns, major elements, $\mathrm{Pb}$ and $\mathrm{Hg}$ were determined in two multicores collected at 445 and $2100 \mathrm{~m}$ water depth (mwd) in the Cascais submarine canyon (CSC). The PAAS-normalized REE patterns suggest mixing of Tagus estuarine and marine sediments, marked by MREE (Nd-Dy series) enrichment and by positive Eu-anomaly, with marine sediments. The positive $\mathrm{Eu} / \mathrm{Eu}^{*}$ implies incorporation of detrital feldspar minerals derived from the estuary. $\mathrm{Ce} / \mathrm{Ce}{ }^{*},(\mathrm{La} / \mathrm{Yb})_{\text {PAAs }}$ and $(\mathrm{Nd} / \mathrm{Yb})_{\text {PAAS }}$ show differences between the two cores. Core 252-35 from the shallower site is enriched in HREE (Ho-Lu series) over LREE (La-Pr series), a pattern also found in the Tagus estuary in the vicinity of an abandoned chemical complex, where the environment is affected by the legacy of massive-sulfide ores processing. There seems to be only limited down-canyon sediment transport to the deeper reaches where core 252-32 was collected. This deeper site shows $\mathrm{Ce} / \mathrm{Ce}^{*}$ peaks coinciding with low $(\mathrm{La} / \mathrm{Yb})_{\text {PAAs }}$ values suggesting preferential diagenetic remobilization of LREE relative to HREE. Upcore $\mathrm{Pb} / \mathrm{Al}$ and $\mathrm{Hg} / \mathrm{C}_{\text {org }}$ trends observed in both cores indicate
\end{abstract}

* Corresponding author at: IPMA - Portuguese Institute of Sea and Atmosphere, Division of Oceanography and Marine Environment, Rua Alfredo Magalhães Ramalho, 6, 1495-165 Algés, Portugal.

E-mail address: mario.milhomens@ipma.pt (M. Mil-Homens). 